\title{
Towards A New Law to Protect Consumers from the Use of Defective Products in Palestine
}

Prof. Mahmoud fayyad ${ }^{1 *}$, Prof. Sayed Ahmad ${ }^{2}$

${ }^{1}$ Associate Prof. College of Law, University of Sharjah, United Arab Emirates

${ }^{2}$ College of Law, University of Sharjah and Ain Shams University, United Arab Emirates

\author{
Article History \\ Received: 30.06 .2020 \\ Accepted: 15.09 .2020 \\ Published: 23.10 .2020 \\ Journal homepage: \\ https://www.easpublisher.com/easmb
}

Abstract: This study aims to highlight the need to enact a new law to protect consumers from the use of defective products. It analyzes the success of the general principles to ensure this protection. The study concludes the need to provide a clear definition for the term consumer, in addition to the ineffectiveness of the general principles to provide an adequate protection which the consumers need in order to enhance the market economy in addition to math the requirements of fair transactions to the interests of consumers. Keywords: Consumer protection, Palestinian law, product liability, defective products.

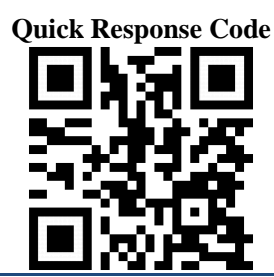

Copyright (C) 2020 The Author(s): This is an open-access article distributed under the terms of the Creative Commons Attribution 4.0 International License (CC BY-NC 4.0) which permits unrestricted use, distribution, and reproduction in any medium for non-commercial use provided the original author and source are credited.

\section{INTRODUCTION}

Nobody can deny the direct link between law and economic developments in the world, with the development of industries and means of transportation and the openness of the world to each other An urgent need for the politicians to facilitate the movement of goods of all kinds is significant, in order to enable producers of goods to access foreign markets, which They may not be in conformity with the specifications in their country of origin, despite their diversity. With the passage of time, the need for foreign industries has become more and more and a very important matter, as the use of these products has become an inevitable matter even if that use causes damage to consumers, as these products have made it easier for consumers to meet the needs necessary for their lives, without being aware of the danger of their use $\left[{ }^{1}\right]$.

When researching the development of industrial products in different countries of the world, this is accompanied by the development in the methods of advertising and the promotion of these products,

\footnotetext{
1 Fayyad, M. (n.d.). A glance at unfair terms in consumer transactions in Arab legal systems and Islamic law: What Arab lawyers can learn from the European experience? International Journal of Private Law, 5(2),

200-227. https://doi.org/10.1504/IJPL.2012.046061
}

which increase the consumer's adherence to these commodities as a result of what the product does of advertising methods at the expense of the public interest of consumers, and from here the idea of legal protection appeared. To the consumer from damages to defective industrial products through the existence of a legal regulation that takes care of the interests of consumers the products, we find that the Palestinian legal system has adopted this protection, by regulating a special law that organizes the consumer's relationship with the product, called the Palestinian Consumer Protection Law, so we find that Article (2) From this law, you detect the goal for which it was set, which is consumer protection, while Article (3) provides for consumer rights which reflects the concern of the law maker with the economic interests of consumers.

On the other hand, the Palestinian law - despite its concern for the consumer - did not give him the appropriate rights in a way that preserves his rights from loss. Therefore, we believe that several issues arise in order to determine the law that should be applied to damages resulting from defective industrial products, both national and imported $\left[^{2}\right]$. And determine

\footnotetext{
${ }^{2}$ For more details see: See M J Trebilcock, The limits of freedom of contract (Harvard university press: Cambridge 1993) 188. M. Hesselink, The politics of a European civil code (Kluwer law international: London 2006) 55. Alshdaifat, Shadi, International Law and the
} 
who is responsible for these damages, and the obligations of both the seller and the producer. $f$ as civil protection is considered one of the most important legal issues at the present time, given that the idea of the consumer is a fundamental idea for the legal system based on protecting the rights of citizens, which requires greater attention from the Palestinian legislator in order to organize this protection $\left[{ }^{3}\right]$. This study investigates the success of the civil general principles of law, which are provided in El-Majallah code- to protect consumers from the damages that are arisen from the use of defected products $\left[{ }^{4}\right]$.

The definition of the contracting parties has a great importance, as consumer protection law aims to protect consumers in addition to what is called unprofessional in facing the final product, which is the strongest party in the contractual relation $\left[{ }^{5}\right]$, which needs to be clarified whether it is the consumer is the buyer in the sense recognized in the general rules in the sales contract? Therefore, we find that those rules set conditions that achieve civil liability for the producer, so that they guarantee that the consumer will obtain his right to compensation, based on the presence of a defect in those products that are contracted for, the occurrence of damage, and the causal relationship that brings them together, in addition to clarifying the double relationship between The final product, with the person of the consumer and others who have damaged that commodity due to a defect in it.

This study focuses the definition of the consumer in terms of narrow and wide approaches which are provided by Arab scholars. In addition, it detects the scope of application of the general principles which protect the weak party in the relation in question. The answer of these questions requires us to divide this study into two parts; the first discusses the scope of law enforcement, while the second evaluates the success of

Use of Force Against Terrorism, Newcastle upon Tyne, UK: Cambridge Scholars Publishing, 2017.

${ }^{3}$ Fayyad, M. (2012). Misleading Advertising Practices in Consumer Transactions: Can Arab Lawmakers Gain an Advantage from European Insight? Arab Law Quarterly, 26(3), 287-311. https://doi.org/10.1163/15730255-12341234.

Alshdaifat, Shadi, The Unmapped Road of the Security Council: Exaggeration vs. Factuality, Kuwait International Law School Journal, Volume 3, Issue 1, 2018.

${ }^{4}$ Fayyad, M. (n.d.). Fundamental breach of contract in terms of the UN Sales convention and emirates law: A comparative legal study. Arab Law Quarterly, 33(2), 109-151. https://doi.org/10.1163/15730255-12332008.

${ }^{5}$ A. Zysow "The Problem of Offer and Acceptance: A Study of Implied-in-Fact Contracts in Islamic Law and the Common Law", Cleveland State Law Review 34/1 (1986): 54. Abbas, Islamic Law in The Contemporary Context (U.K.: Stanford University Press, 2007) 18. the general principles of product liability to reach the optimal protection.

\section{The target of protection}

In defining the idea of a consumer there are two challenges: A broad trend that takes a comprehensive concept of the consumer regardless of the goal behind the contractual process, and a narrow trend that defines a specific concept, and sets narrow criteria for consideration of the person Consumed. Is the legal person considered, according to the narrow concept, a consumer? To what extent has the Palestinian politicians adopted the concept of the consumer?

\subsection{The need to rethink about consumer definition}

The contractual relationship in depreciation contracts consists of; The consumer who represents the weak party in the contractual process, and who must be protected by civil to preserve his rights from loss, and the other party who represents the final product of the commodity and who has the experience and know-how in facing the consumer $\left[{ }^{6}\right]$.

The narrow concept of the consumer is defined as: every person contracts with the aim of meeting his personal or family needs, and thus does not acquire the status of a consumer, whoever contracts for the purposes of his profession in accordance with this concept.

The consumer is also defined as: the person who buys goods and services for his personal and family use and is not related to his professional activity. However, there is a difference between legislation, whether the consumer is a natural person only, or the legal person falls within this concept, such as charities and trade unions that do not aim to make a profit, but rather seek to meet the needs of the people they serve $\left[{ }^{7}\right]$. Therefore, the consumer, according to this concept, revolves around looking at the goal of that consumption (personal consumption). If the consumer contracts with another, then the goal must be to satisfy the personal and family needs only $\left[{ }^{8}\right]$. If a person who owns carpentry purchases a television for use while he is doing his work, then it is not considered as part of personal consumption according to this concept, but rather it is related to his professional activity. Therefore, the legal person cannot be considered a consumer, for

\footnotetext{
${ }^{6} \mathrm{E}$ Houndous, the reception of the directive on unfair terms in consumer contracts by member states (1995) 3 European Review of private law 246.

${ }^{7}$ Alshdaifat, Shadi, et al., Harmonising Regulatory and Antitrust Regimes for International Air Transport, 1st ed. Oxford: Routledge, Taylor \& Francis, 2018.

${ }^{8}$ A. Zysow "The Problem of Offer and Acceptance: A Study of Implied-in-Fact Contracts in Islamic Law and the Common Law", Cleveland State Law Review 34/1 (1986): 54. Abbas, Islamic Law in The Contemporary Context (U.K.: Stanford University Press, 2007) 18.
} 
the Palestinian Cellular Communications Company purchases a set of heating devices to be used while its employees are working is not part of personal consumption, but rather is related to the professional activity of that company. As a result, a person cannot be considered a consumer if the subject matter of the commodity is related to a professional activity, and thus the legal person cannot be considered a consumer in any way according to this concept $\left[{ }^{9}\right]$.

The broad concept of consumer is defined as: everyone who takes any legal action. So, he is the person who makes the contract, in order to use goods and services for his personal or professional use, and he may be a natural person, or a juridical person $\left[{ }^{10}\right]$. The professional meaning of consumption falls within the scope of this concept. Therefore, we consider every person who purchases goods for their consumption, regardless of the purpose of this consumption, whether personal or professional, he is a consumer, and as a result, whoever buys a car for his personal use or for his professional use is subject to the protection prescribed for this party. The lesson from this criterion is that the subject matter of the commodity is not related to the primary activity of the trader, but rather that the purpose behind the contractual process is personal or professional use. If the contractual process involves a business related to a commercial activity, such as a merchant purchasing a large transport vehicle to be used in transporting the items sold from the commercial store and delivering them to their owners, then the purchase of that car is related to the primary activity of the merchant and does not fall within this concept. It is defective or fraud has occurred by the seller of the car. Rather, it is subject to the trade law that governs the relationship of dealers with them. For example, if the bank wants to buy a set of air conditioners, in order to put them and use them during the official working hours, for employees and they are defective, is this commodity considered to have been purchased for a professional or personal purpose? According to the narrow concept, the purpose behind buying it should be the personal purpose $\left[{ }^{11}\right]$. As it turns out, it is subject to

9 A Zogrood, the hotel obligations of civil responsibilities in the face of the tourist or the customer, a comparative legal study (1993) 28 the Journal of legal and Economic researches 32.

${ }^{10} \mathrm{E}$ M Weitzenbock, Good faith and fair dealing in contracts formed and performed by electronic agent (2004) 12 Artificial Intelligence and Law 86. L Hawthorne, Abuse of right to dismiss not contrary to Good faith (2005) 17 SA mercantile Law Journal 218. $\mathrm{N}$ Lockett and $\mathrm{M}$ Egan, unfair terms in consumer agreement, the new rules explained (Chancery law publishing Ltd: England, 1995) 45.

11 Alshdaifat, Shadi, Silverburg, Sanford, Syrians Displaced by Civil Conflict: What are the Implications from International Law? Connecticut Journal of the protection rules established in this law. But if its purpose is professional, then it does not fall within the scope of this concept. If we are in the context of the broad concept, whether the purpose behind its purchase is personal or professional, it falls within this concept, and the protection rules established for it are applied to it $\left[{ }^{12}\right]$. Consequently, according to the first criterion, the bank is not considered a consumer and is not subject to the protection rules established for it. Whereas, it falls within the scope of the consumer in the second criterion and is subject to those rules.

The Palestinian Consumer Protection Law $\left[{ }^{13}\right]$ in Article (1) of it, defines the consumer as: "Whoever buys or benefits from a good or service". This provision makes clear that the Palestinian legislator has adopted the broad concept of launching it, and has included everyone who has an interest in buying a good or service under the content of this concept, which indicates that, regardless of the purpose behind purchasing this commodity, whether it is for personal or professional use, it is subject to According to the rules of protection established in this law, and therefore we are facing a great contradiction in the context of the provisions of the law themselves, where we find that the articles that determine this protection are understood to be designed to protect the weak party in the contractual process, who does not have experience and knowhow $\left[{ }^{14}\right]$. Therefore, these articles stipulated rules to protect his rights that are consistent with the technical rules $\left[{ }^{15}\right]$. Accordingly, the legislator adopted the narrow concept of defining the consumer, while we find that he defined the consumer according to the broad standard, thus raising the question about the intention of the legislator! Did he want to adopt narrowing the concept of the free consumer with civil protection? Or did he want every person to be a consumer regardless of the purpose of the contractual process? Thus, he

International Law, USA. "The leading Article", Vol. 31, (2), pp. 141-161 (2016).

12 M.H. Kamali, "Islamic Commercial Law: An Analysis of Futures", the American Journal of Islamic Social Sciences 13/2 (2005): 197. M. Azmin, "The Theory of Contract and Formation of Contract: a Comparative Study Between Islamic Law and Common Law as Practiced in Malaysia" Petaling Jaya, University Malaysia, Malaysia: international Islamic (1993).

${ }^{13}$ Fayyad, M. ( 1,2 ). (n.d.). The transposition of the European directive $85 / 374 / \mathrm{EEC}$ on product liability into palestine and Jordan: Is it adaptable to islamic law? Global Journal of Comparative Law, 1(2), 194 224. https://doi.org/10.1163/2211906X-00102003.

${ }^{14}$ Alshdaifat, Shadi, A Visible Theme in the History of International Law: International or Global? Int. J. Public Law and Policy, Vol. 6, No (1), 2017.

15 A. Sarhan and N. Khatir, the Explication of Jordanian law, Resources of personal Rights "Obligations" (Amman: Dar AL-Thaqafa, 2009) 58-59. 
provided a large number of people with the protection guaranteed by this law.

Therefore, the Palestinian legislator should have adopted a specific concept without the other, so as not to fall under the pain of contradictions in its provisions.

\subsection{The need to rethink about supplier definition}

Various legislations have been concerned with protecting the consumer, and the rules that regulate this protection have been laid down and are in his interest, but they differed in defining the concept of the product, and on whom the responsibility lies in ensuring the hidden defects $\left[{ }^{16}\right]$. Some of them have determined the product but expanded the arrangement of this responsibility when there is more than one product, but The Palestinian legislator defined it in its definition of the product, in Article (1) of the Palestinian Consumer Protection Law, saying: "A person who practices in his name or for the account of others an activity that is to distribute, trade, manufacture, rent goods, or provide services."

Thus, we see that the Palestinian legislator has adopted a broad concept, as this concept included many people with whom the commodity passes from the beginning of its existence to its arrival to the consumer, who may be a natural or moral person. Here the question arises $\left[{ }^{17}\right]$ who is responsible for compensating the consumer for damages Defective products? We find that the Consumer Protection Law in Article (10) of it stipulates: "The ultimate supplier shall be liable for damage resulting from the use or consumption of the local or imported product that does not meet the safety or health conditions for the consumer, or does not adhere to the declared or agreed upon guarantees, unless proven $\left[{ }^{18}\right]$. The identity of the person who provided him with the product and also proved that he is not responsible for the damage caused [ $\left.{ }^{19}\right]$.

${ }^{16}$ D. Kennedy, "From the Will Theory to the Principle of Private Autonomy: Lon Fuller's "Consideration and Form”, Colombia Law Review Journal 100 (2000): 94.

17 Alshdaifat, Shadi, Silverburg, Sanford, "Strategic Chaos": The Role of International Law, SJHSS, Vol. 2, Issue.7, 2017.

18 M.H. Kamali, "Islamic Commercial Law: An Analysis of Futures", the American Journal of Islamic Social Sciences 13/2 (2005): 197. M. Azmin, "The Theory of Contract and Formation of Contract: a Comparative Study Between Islamic Law and Common Law as Practiced in Malaysia" Petaling Jaya, University Malaysia, Malaysia: international Islamic (1993).

${ }^{19}$ Fayyad, M. (2013). Classification of Contractual Agreements in Comparative and Islamic Jurisdictions: Does it Make Any Sense? Arab Law Quarterly, 27(3), 203-229. https://doi.org/10.1163/15730255-12341256
Consequently, the legislator stated that the responsibility rests on the final supplier vis-à-vis the consumer, and thus he wanted to limit that responsibility to help the consumer identify the responsible person, given that the final supplier is the one who has the ability to know the stage in which the commodity was damaged, in addition to his ability to determine liability The person who supplied him with the product $\left[{ }^{20}\right]$ if he proves that, the responsibility falls on whoever has been proven responsible. Moreover, he can insure the products in his possession from any risk. From here we conclude, that the legislator wanted to help the consumer (the weak party), in facing the product that is the strongest party in the contracting process.

On the other hand, we find that the Palestinian Trade Bill considered that the final product is "the manufacturer of the commodity who prepared it in its final form in which it was presented in circulation, whether all the parts that make up the commodity were made by him or he used parts of the manufacture of others, and the word does not deviate to the followers of the product." The legislator considered that the one responsible for compensation is the final producer of the commodity and not the final seller $\left[{ }^{21}\right]$.

After highlighting the concept of both the producer and the consumer, and the legislator adopting the broad concept and defining the concept of the defective product, we would like to talk about the general rules governing consumer protection (the weak party in the contractual process) according to the Palestinian legal system.

\section{The assessment of the general principles of law}

Civil liability is based on general rules governing product liability vis-à-vis the consumer, so when talking about this liability we must address its conditions and elements, including fault as a basis for liability, the occurrence of damage, and the causal relationship between them, so that it consists of a contractual liability that includes a contractual relationship between the final product and the consumer who represents the weak party in that relationship, and which necessitates a guarantee in case of breach of it; A tort liability based on the existence of a harmful act, and what is the dual legal nature that binds the producer to

\footnotetext{
${ }^{20}$ H. Beal, B. Fauvarque, J. Rutgers, D. Tallon and S. Vogenaure, Cases, materials and Text on Contract law, (U.K.: Hart Publications, 2010) 46.

21 M.H. Kamali, "Islamic Commercial Law: An Analysis of Futures", the American Journal of Islamic Social Sciences 13/2 (2005): 197. M. Azmin, "The Theory of Contract and Formation of Contract: a Comparative Study Between Islamic Law and Common Law as Practiced in Malaysia" Petaling Jaya, University Malaysia, Malaysia: international Islamic (1993).
} 
the consumer? Therefore, we will address the answer to these questions in this section of the study.

\subsection{Conditions of supplier liability}

Product liability is achieved by the availability of three conditions, including fault as a basis for civil liability, the occurrence of damage to the consumer $\left[{ }^{22}\right]$ and the existence of a causal relationship between the fault and the damage, which we will deal with in succession as follows:

\section{First: the condition of fault}

The pillars of civil liability are similar in its two parts, contractual and default, as a result of the development of the jurisprudence in legal concepts $\left[{ }^{23}\right]$ and since the relationship that binds the producer to the consumer is subject within the framework of the contractual relationship in the largest part of it, we examine the contractual responsibility that brings them together $\left[{ }^{24}\right]$.

Fault in the jurisprudence of the law is defined as: a breach of a legal duty, whether it is an obligation in contractual liability, or it is a general duty as in tort, it is not sufficient to consider a person as a breach of his duty as soon as the material incident becomes available, whether the obligation is not implemented or flawlessly executed $\left[{ }^{25}\right]$. There must be a moral element, which is the ratio of the incident to the person assigned to implement it, that he has failed to implement the obligation and otherwise is not considered wrong $\left[{ }^{26}\right]$. The debtor (the final product) according to the Consumer Protection Law is considered to have committed a mistake in the face of the creditor (consumer), if he did not implement his obligation in the manner specified in the contract, or the implementation of his commitment was partial or

${ }^{22}$ Fayyad, M. (2014). Measures of the Principle of Good Faith in European Consumer Protection and Islamic Law, a Comparative Analysis. Arab Law Quarterly, 28(3),

https://doi.org/10.1163/15730255-12341283

23 S. Michida, "Possible Avenues to Preparation of Standard Contracts for International Trade on a Global Level in Unification of the Law Governing International Sale of Goods", in John O. Honnold (ed), Colloquium on National and Regional Unification of the Law of Sales (New York: Hart, 1966) 267.

${ }^{24}$ Fayyad, M. (2014). Measures of the Principle of Good Faith in European Consumer Protection and Islamic Law, a Comparative Analysis. Arab Law Quarterly, 28(3), 205-230. https://doi.org/10.1163/15730255-12341283.

${ }^{25}$ Alshdaifat, Shadi, Regulating the Military Action in International Law: A Diplomatic Solution Approach The Iraqi War, SJHSS, Vol. 2, Issue. 11, 2017.

${ }^{26}$. Kessler and E. Fine, "Culpa in Contrahendo, Bargaining in Good Faith, and Freedom of Contract: A Comparative Study", International Journal of private law (1994): 401. defective. The Jordanian Civil Law indicated that in the event of failure to implement the obligation as a result egligence and negligence, it is considered a mistake that necessitates contractual liability on the final product $\left[{ }^{27}\right]$. If the consumer buys a defective car, without the final product informing the consumer of the hidden defect in it, it cannot be known, and that defect in that car led to an accident that caused physical and material damage. He committed a serious mistake that necessitates responsibility as a result of negligence and negligence, which necessitates the obligation to achieve the required result of the contract, namely, buying the car free from defects in this example, and this is known as a positive fault, which includes the issuance of a wrong act by the final producer in the implementation of his commitment, on the other hand, we find The negative fault revolves around refraining from performing a duty imposed on him by the contract concluded between the final product and the consumer, such as the failure of the producer to inform the consumer that there is a defect in the sold product and here we are not in the wrong A serious consequence of failure, but willful failure to perform a duty imposed by the contract between the two parties, and thus refraining is considered a mistake that necessitates responsibility. If a person purchases a quantity of the agricultural crop that was sprayed with a large amount of chemical materials and the final product is aware of this, he concealed the danger of this product and refrained from informing The buyer by that, which caused the pain poisoning of the buyer and his family, and thus, we see that abstaining is subject to the general rules that regulate the fault. In a judicial ruling of the Court of Cassation that is taken by way of conciliation, where it said: The decision of the Jordanian Court of Cassation in its capacity as a jurist, the fault is the first pillar on which the tort liability is based, if the plaintiff bases in her lawsuit that the defendant's employees 'fault in conducting and issuing informational reports is the basis of their responsibility With regard to the damage that has befallen it, it has the right to prove the occurrence of this fault with the technical expertise, considering that the technical expertise may not be refuted except by the technical expertise by conducting the technical expertise by examining the expert or experts on the laboratory reports and the examinations highlighted in this case $\left[{ }^{28}\right]$, as well as what proved to the court from its facts considering that it has become impossible to conduct experience on samples of imported fish shipments that are the subject of the lawsuit after all this time has passed, and in application of the total rule that says that the description in the

27. Kessler and E. Fine, "Culpa in Contrahendo, Bargaining in Good Faith, and Freedom of Contract: A Comparative Study", International Journal of private law (1994): 401.

${ }^{28}$ Fayyad, M. Organization of Contractual Agreements in Islamic Law, a Comparative Legal Study with Western Legal Systems, European journal of Social Science, Vol. 55, Issue 1, 2017, P. 40-54. 
present is nonsense and in the absent, this is considered to determine whether the laboratory reports and the results of the examinations issued by the employees of the defendant are correct or wrong and if they are mistakenly, does the element of fault necessary for the establishment of negligent liability on the side of the defendants be found in it? It may be premature and revocable $\left[{ }^{29}\right]$.

We have already indicated, the gross fault that is devoid of intent to damage the consumer is the result of negligence, but the intentional fault that involves fraud associated with fraud and deception on the consumer, and that is by showing actions that lead the consumer to buy the defective product by false and misleading means, and as a general rule must Cheating is accompanied by obscene fraud, but in this regard we are talking about fraud accompanied by fraud in defective products $\left[{ }^{30}\right]$. We find that the legislator has established single rules for fraud and serious fault.

We get rid of it; That the fault must be the basis for the establishment of civil liability for the product, whether it is a serious mistake or intentionally accompanied by fraud and fraud, there must be a defect that leads to damage to the consumer financially and physically in order for the responsibility to be established, because the presence of the fault alone is not sufficient to achieve the damage, but rather there must be a defect in the product Who he offers.

\section{Second: the condition of Damage}

The damage is considered one of the essential pillars on which civil liability is based, as there is no liability without damage resulting from the fault or the harmful act, which is the cause of the result (damage), as the Palestinian Court of Appeal stated that not to damage others is a legal obligation, and that damage to others Compensation is required based on tort, whether there is a criminal liability or not. And since the Code of Judicial Rulings is the basis for governing the civil rules in the Palestinian legal system, as Article (19) stipulates that: "No damage," it is understood from it that it is not permissible for a person to sell to another sold money without informing him of the defect in the money. Hiding the defect from the buyer is considered damaging it. And in a decision of the Jordanian Court of Cassation in its legal capacity No. $1797 / 2005$ by way of taking all the damages to third parties, the perpetrator is obliged to guarantee the damage and the guarantee is assessed in proportion to the extent of the damage and lost earnings suffered by

${ }^{29}$ A. Zysow "The Problem of Offer and Acceptance: A Study of Implied-in-Fact Contracts in Islamic Law and the Common Law", Cleveland State Law Review 34/1 (1986): 54.. Abbas, Islamic Law in The Contemporary Context (U.K.: Stanford University Press, 2007) 18.

30 Alshdaifat, Shadi, Idealism and Realism in International Relations: A Dichotomy of Failure, Journal of Law, University of Bahrain, 2019. the injured, and as stated in Articles 256 and 266 of the Civil Code, and the claimant is required to pay compensation for the damage $\left[{ }^{31}\right]$. The person who was affected by the plot of land as a result of the road passing through it has a right claim, regardless of the reason on which the road was relied upon, whether through acquisition or without it, as long as the damage was caused to that land, in contrast to what the Court of Appeal concluded in its distinct decision that the claim resulting from Forger and encroachment mentioned in Article 279 of the Civil Code differs from the nature of the claim for damage resulting from the work of a project resulting from the expropriation, which is represented by a decrease in value, since in both cases it does not preclude the right of the victim to claim compensation $\left[{ }^{32}\right]$.

The study of damage requires addressing the types and conditions necessary for its realization, so its types revolve around the material damage that befalls the person in his financial responsibility, the moral damage that he inflicts on his reputation, and the personal damage that he inflicts on his body, which falls within the framework of the consumer's subject by selling the consumer defective products that expose him to damage Profile, and as a result; Personal damage shall result in indemnification of the consumer for the damage he suffered in accordance with the rules of civil liability $\left[{ }^{33}\right]$.

Accordingly, in order to realize the damage resulting from the mistake of the final product in supplying defective goods, three conditions must be met:

1. If the damage is immediate or has occurred: damage is considered immediate if it does happen, such as if the injured person is injured in his body. A person who suffers a permanent disability as a result of using a defective product can claim compensation not for the damage that occurred as a result of his inability to work immediately, but also for The damage that will inevitably occur in the future, that is, the financial loss that befalls him because of his inability to earn, and this constitutes all that he would have obtained from his work in the future of his life, and the damage will be realized if it did not happen, but it is inevitable that it

\footnotetext{
${ }^{31}$ Alshdaifat, Shadi, Who Owns What in Outer Space? Dilemmas Regarding the Common Heritage of Mankind, Pécs Journal of International and European Law, Vol II, 2019.

32 Dr. Mahmoud Fayyad, Prof. Abdulellah AlNawaysieh, and Dr. Shadi Alshdaifat, The Legal Notion of the Indicative List of Unfair Terms Provided in the European Directive (93/13) Of Unfair Terms in Consumer Contracts, East African Scholars Multidisciplinary Bulletin, Vol. 2, Issue 8, 2019, P. 282-292.

33 E. Allan Farnsworth, "Meaning in the Law of Contracts", Yale law Review Journal 76 (1967): 939.
} 
will happen in the future. Thus, the damage likely to fall into contractual liability is not taken into account for the cost of compensation $\left[{ }^{34}\right]$.

2. The damage must be direct: contract liability is realized if the damage is a natural result of a contractual fault, that is, it is a result of the debtor's breach of his contractual obligation $\left[{ }^{35}\right]$. For example, if a person working for Coca-Cola bought a defective car without the seller notifying and seeing this defect, that is, he committed an intentional mistake and as a result Therefore, if a person was exposed to an accident that led to the amputation of his hand and his inability to work, then the company dispensed with his services, and this in turn led to his children leaving the university, then all of these damages that resulted from the first accident (direct damage) are considered indirect damages and the seller is not asked about them because they are Abnormal result of nodal fault;

3. The damage must be foreseeable: the debtor is asked about the expected damage at the conclusion of the contract, and thus compensation is only made on the basis of the expected damage without the unexpected damage, such as the consumer contracting with the producer to buy a used car that broke down a month after its purchase, so that this failure is from It is assumed that it is from the damages that are expected during the conclusion of the contract $\left[{ }^{36}\right]$. However, an exception is made from this rule when talking about unexpected damage resulting from fraud or a gross fault on the part of the debtor, and thus the provisions that apply in this case the rules of default, because the contracting parties in contractual liability determine the expected damage at the conclusion of the contract $\left[{ }^{37}\right]$ so an unexpected damage occurs to the creditor as a result Fraud and fraud, which leads to disrupting the role of the power of will and thus obligating him to compensate for expected and unexpected damage $\left[{ }^{38}\right]$.

${ }^{34}$ Fayyad, M. and others the regulatory Frame of Modification Clauses in Palestine and English Law, Global Academic Journal of Economics and Business; 2020, volume 2, issue 2.

${ }^{35}$ Dr. Mahmoud Fayyad \& Prof. Sayed Ahmad;(2020). The Regulatory Frame of Modification Clauses in Palestine and English Law, Global Academic Journal of Economics and Business, Vol- 2, Iss-2 pp-31-34

${ }^{36}$ E. Allan Farnsworth, "Meaning in the Law of Contracts", Yale law Review Journal 76 (1967): 939.

${ }^{37}$ A. Zysow "The Problem of Offer and Acceptance: A Study of Implied-in-Fact Contracts in Islamic Law and the Common Law", Cleveland State Law Review 34/1 (1986): 54. Abbas, Islamic Law in The Contemporary Context (U.K.: Stanford University Press, 2007) 18.

${ }^{38}$ Alshdaifat, Shadi, The Evolving of Investments in the National and International Regime: The Way Forward, Kuwait International Law School, Vol. 8, Issue 8, 2020.
From the above, we conclude from that, that the damage must occur in order for civil liability to be established, as it is an inevitable consequence of the occurrence of the fault so that there is liability.

\section{Third: Causation between fault and damage}

The establishment of civil liability requires the existence of a causal relationship between the fault and the damage, linking the occurrence of the fault and the realization of the damage that is considered a result of the fault that occurred. Therefore, it cannot be said that civil liability has been achieved until after confirming the fault that led to the occurrence of the damage, and thus a causal relationship between them. Whereas, the Palestinian Court of Appeal stated in its ruling that the elements of negligent liability are fault and damage, and the causal relationship between the fault and the damage, and if the municipality is responsible for the electrical poles that resulted from the accident, then its responsibility is considered presumptive and it has the burden of proving the dissolution of this responsibility. The debtor's failure to fulfill his obligation, which in turn led to the occurrence of damage to the creditor, is represented in a direct relationship between committing the mistake and obtaining the damage requiring compensation $\left[{ }^{39}\right]$. However, it is difficult to prove the causal relationship if there is more than one result for the same reason. There is a damage resulting from the debtor's mistake, in addition to the liability in compensation that is based only on the first mistake if there is more than one mistake, due to the lack of a causal link between the fault and the damage in this case.

\section{The legal notion of liability}

Defective products cause great damage not only to the contracting consumer, but to exceed their role to others, which imposes double civil liability on the final product vis-à-vis the consumer. As well as arranging tort liability only, on the final product facing third parties affected by those products.

\section{First: The contractual liability}

Contractual liability is evident when talking about the contractual relationship between the final product and the consumer, which must be established, the existence of a contract between the responsible and the injured, and the period before and after the contract is outside of its scope, and that the contract between them is correct, arranged for all its effects, in addition to this damage. It may arise from the breach of the obligation imposed by the contract, in the event that there is a defect in production, or if the production is sound and free from every defect, but it is dangerous, and thus everything else is outside the scope of

39. Kessler and E. Fine, "Culpa in Contrahendo, Bargaining in Good Faith, and Freedom of Contract: A Comparative Study", International Journal of private law (1994): 401. 
contractual liability $\left[{ }^{40}\right]$. Thus, the consumer (the contractor) alone is entitled to claim compensation in accordance with the contractual liability rules for damages expected to occur upon the conclusion of the contract with a direct claim.

However, the provisions of tort liability are applied to the contractual relationship in the event that the final product breaches the contract by committing a serious mistake as a result of negligence, and by committing an intentional mistake resulting from fraud and deception, which compels the consumer to purchase a defective and dangerous commodity that would damage him. The final product, in accordance with the provisions of tort that guarantees him obtaining full compensation for direct damage. Therefore, it is necessary to differentiate between the fault as a basis for contractual liability, which results in being subject to its provisions, and the gross and willful fault that subjects the product to the provisions of tort liability, even if the fault results from a contractual relationship.

\section{Second: tort liability}

Tort liability is established in the event that a person breaches an obligation imposed by law, which is not to damage a third party with whom he is not related to any contractual relationship of the person responsible for the damage. Therefore, the damage in this case is beyond the scope of the bond that binds them $\left[{ }^{41}\right]$. The third party is represented by the buyer who examines the sale before concluding it, and the members of the buyer's family and friends who call to his home and were damaged by eating the defective product and others who do not have a contractual relationship with the defective product, so that the final product is not required only for compensation for the damage arising from his action, but for the damage that occurs by doing things The responsibility of the shopkeeper for the injury that befalls his client in his capacity as a guard, for example, is of a negligent nature, such as slipping the customer's foot on the floor of this shop as a result of the presence of water on it or because of the same thing desired to be purchased, such as the explosion of a soda bottle in the hands of the customer while he is paying for it. We conclude from this that the liability that comes with the product varies according to the different parties to the relationship, whether that relationship is between the producer and the consumer or it is with others.

\section{CONCLUSION}

This study proves the need to regulate more special and related rules in order to ensure an adequate protection for consumer from the use of depictive products in the national market. Rules which are provided in the general principles of law in addition to those which are provided in consumer protection law do not math this requirement. It is clear from this study that the intended consumer is the person who purchases the goods for his personal and professional use. Thus, the legal person does not fall within this concept. In addition, the rules for consumer protection do not differ from the general rules in the sales contract, especially since the Palestinian consumer protection law did not clarify these rules, but rather implicitly referred them to the general rules.

40 E. Allan Farnsworth, "Meaning in the Law of Contracts", Yale law Review Journal 76 (1967): 939.

${ }^{41}$. Kessler and E. Fine, "Culpa in Contrahendo, Bargaining in Good Faith, and Freedom of Contract: A Comparative Study", International Journal of private law (1994): 401. 